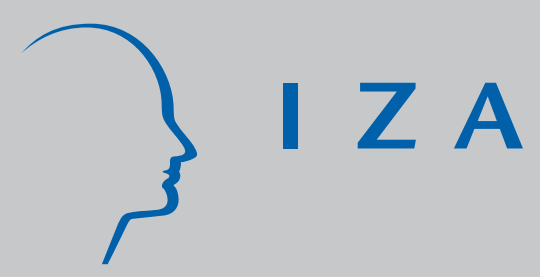

IZA DP No. 106

J ob Tenure of Two Cohorts of Young German Men 1979 - 1990: An analysis of the (West-) German Employment Statistic Register Sample concerning multivariate failure times and unobserved heterogeneity

Lutz Bellmann

Stefan Bender

Ulrich Hornsteiner

J anuary 2000 


\title{
Job Tenure of Two Cohorts of Young German Men 1979 - 1990: An analysis of the (West-)German Employment Statistic Register Sample concerning multivariate failure times and unobserved heterogeneity
}

\author{
Lutz Bellmann \\ Stefan Bender \\ Ulrich Hornsteiner \\ Commerzbank Frankfurt \\ Discussion Paper No. 106 \\ January 2000 \\ IZA \\ P.O. Box 7240 \\ D-53072 Bonn \\ Germany \\ Tel.: +49-228-3894-0 \\ Fax: +49-228-3894-210 \\ Email: iza@iza.org
}

Institute for Employment Research and IZA, Bonn

Institute for Employment Research and IZA, Bonn

This Discussion Paper is issued within the framework of IZA's research area Mobility and Flexibility of Labor Markets. Any opinions expressed here are those of the author(s) and not those of the institute. Research disseminated by IZA may include views on policy, but the institute itself takes no institutional policy positions.

The Institute for the Study of Labor (IZA) in Bonn is a local and virtual international research center and a place of communication between science, politics and business. IZA is an independent, nonprofit limited liability company (Gesellschaft mit beschränkter Haftung) supported by the Deutsche Post AG. The center is associated with the University of Bonn and offers a stimulating research environment through its research networks, research support, and visitors and doctoral programs. IZA engages in (i) original and internationally competitive research in all fields of labor economics, (ii) development of policy concepts, and (iii) dissemination of research results and concepts to the interested public. The current research program deals with (1) mobility and flexibility of labor markets, (2) internationalization of labor markets and European integration, (3) the welfare state and labor markets, (4) labor markets in transition, (5) the future of work, (6) project evaluation and (7) general labor economics.

IZA Discussion Papers often represent preliminary work and are circulated to encourage discussion. Citation of such a paper should account for its provisional character. 


\title{
ABSTRACT \\ Job Tenure of Two Cohorts of Young German Men 1979 - 1990: An analysis of the (West-)German Employment Statistic Register Sample concerning multivariate failure times and unobserved heterogeneity
}

\begin{abstract}
Based on theoretical models of job mobility this paper provides an empirical analysis of job durations in West Germany using information from two cohorts of new entrants to the labor force. We adopt an accelerated failure time model allowing for unobserved heterogeneity. Thereby we combine the generalized estimating equations approach with the replacement of censored times by imputed values. The most important results are that employees stay longer in larger establishments and in production industries. Older individuals, those with completed apprenticeship training and those coming directly from apprenticeship training have longer job durations. In contrast, the larger the number of unemployment and employment spells, the shorter is the job attachment expected.
\end{abstract}

JEL Classification: J62, C41

Keywords: Occupational mobility, unemployment, duration analysis

Lutz Bellmann

Bundesanstalt für Arbeit

Institut für Arbeitsmarkt- und Berufsforschung

Regensburger Str. 104

90327 Nürnberg

Deutschland

Tel: +499111793046

Fax: +499111793297

Email: lutz.bellmann@iab.de 


\section{Introduction}

The OECD (1993) has documented that the majority of workers in industrialised countries can look forward to find a stable employment relationship. However new entrants to the labor force experience high turnover. Promoting institutions which support longer tenures and worker participation (or „voice“ in the firm) utilize strategies to encourage enterprise and employee efforts in skill formation and training. The results of the OECD (1993) study show that attachments between employee and employer are more likely to endure for Japanese, French and German workers. Furthermore Germany has the highest share of young new recruits who received any formal training from their employer. For Germany in $198971.5 \%$ of young new recruits completed apprenticeship training, whereas in the U.S. only 10,2\% of young new recruits trained at any job within 7 years after leaving school in the 80s (cf. OECD 1993, 137).

It is sometimes assumed that employment protection policies have been exogenously imposed, and thus probably impair efficiency. However, research on the micro-economics of labor markets has shown that employers maybe interested in long-term employment relationships (cf. Levine 1991). Here, the job training model focusing on the importance of human capital investment, specially the job shopping and matching model stressing the process of information gathering through employment experience should be mentioned. In such models employment protection legislation has not only desirable distributional effects but also help to ensure efficient outcomes. Therefore, it is important to assess the relevance of micro-economic theories empirically.

This paper provides an empirical analysis of job durations in Western Germany using information from more than 8000 members of two cohorts of new entrants to the labor force documented in the (West-)German employment statistic register sample (cf. Bender and Hilzendegen 1995). The appropriate empirical technique to study job length is event history or survival analysis. In labor market research survival analysis has primarily focused on explaining the length of unemployment spells. Application of this technique to employment is less common because huge longitudinal data sets are needed. ${ }^{1}$ Apart from testing hypotheses about the effect of personal characteristics and labor demand variables (e.g. firm size and industry affiliation) we will assess the influence of heterogeneity of the member of the two cohorts on their duration profile. Whereas Schasse (1991) used standard methods (Cox model, Weibull and log-logistic distribution), this paper presents an

1 Exceptions are Meitzen (1986), Berkovec and Stern (1991), Gronberg and Reed (1994), Farber (1994) and, for Germany, Schasse (1991). 
application of a Generalized Estimating Equation framework for event history analysis. The applied model and estimation method has the advantage to allow for unoberserved heterogeneity and correlation between the clustered failure times of one employee as well as for right-censored spells. Our analysis is not restricted to the beginning of the working life of the employees. Since it is not possible to control for all the variables that distinguish one individual's decision from another's, proxy variables for heterogeneity are included in the analysis as well as a model allowing for unoberserved heterogeneity is estimated. A special advantage of the method used for the parameters is the provision of a measure for the amount of "unobserved heterogeneity". However, the individual retirement decision is affected by employment protection and early retirement regulations which differ widely between the firms. The respective data are missing in the employment statistic register, so that the retirement decision cannot be modelled explicitly.

The paper is organized as follows. In section 2 we survey the job training and the job matching model. In section 3 we present our empirical model and the data set. The results are discussed in section 4. Finally, in section 5, a summary is given.

\section{Hypotheses}

In this section theoretical arguments from the specific human capital model, job search, job shopping and job matching theory are presented in order to derive the testable hypotheses about the determinants of the duration of job spells.

In contrast to the other theories mentioned the specific human capital model emphasizes the returns of long lasting jobs. Apart from the firms' human capital investments in their employees, hiring costs (advertising, interviewing, etc.) and screening costs will arise. The larger the employee's human capital endowment the higher the potential earnings stream to be expected (even at investment levels which are relatively low for some time). Insofar both the employer and the employee have contributed to the costs to finance the employee's human capital stock, a long-term employment relationship should be optimal for both sides. However, the potentially distorting effect of contract enforceability and asymmetric information of efficient employment relationships (cf. Parsons 1986) require more complicated compensation packages and complex theoretical considerations. 
Furthermore, the relationship between general and specific human capital is not clear (cf. Parsons 1972, Hashimoto 1979). There are cases where firms undertake job specific training only for those employees with a certain level of general human capital endowment. They argue that already trained employees are easier and cheaper to be trained further, because those persons have learned to learn. This view contrasts with the argument that the financial resources of each individual employee are limited so that she has the choice between general and specific human capital formation. Under the assumption that more job specific human capital increases the job duration, a positive correlation of job duration and proxies for general human capital is expected in the first case, whereas in the second case a negative correlation should arise.

Stevens $(1994,1996)$ has pointed out the so-called poaching problem. Under imperfect competition, firms have some market power, and consequently workers 'wages turn out to be less than thein marginal products. Thus workers cannot appropriate all the returns to their training. Furthermore, the greater the mobility of workers among firms the more potential benefits from training accrue not only to the trainings providing firms but also to other firms. These arguments suggest that market failure exist in the provision and aquisition of training. They shed new light on the apprenticeships systems. Apprenticeships are viewed by Booth and Satchell (1996) as an institutional response to the poaching problem, allowing firms to bear al least some of the costs of training provision during the period of ,indenture“.

Search theory models the worker's problem of finding employment in a decentralized labor market. Information regarding the location of vacant jobs and the compensation that they offer is recognized as imperfect. Therefore, the search process is costly for workers. The existing literature examines whether or not the search costs are higher for those specialising in search activities i.e. people unemployed or out of work, and employees who continue the search for a better employment opportunity. In a model developed by Mortensen (1986) the search effort is endogenously determined. The propensity to separate from a job is positively correlated with the search effort on the job which is negatively associated with the wage earned on the job. However, long job durations and high wages as well as short job durations and low wages may simultaneously be \$ermined\$. They could be regarded as the result of successful matches (after succesful search activities). ${ }^{2}$

\footnotetext{
${ }^{2}$ A disadvantage of the empirical model applied is that until now simultaneous estimation is not possible. Therefore, in contrast to Schasse (1991) we cannot test for the influence of wages on job tenure.
} 
In the original search model and the search on the job extension, information is regarded as imperfect concerning the location of vacant jobs, but the relevant characteristics for a located job are known. Job shopping (cf. Johnson 1978, Jovanovic 1979, Viscusi 1980) and job matching models (cf. Hartog 1981) relax this assumption. The worker must spend some time on the job in order to find out whether the job characteristics and his abilities match one another. Conversely the employers need some period during which they employ and test the match between the employee's abilities and the job characteristics.

Whereas in Viscusi's model the employee acts as a Bayesian forecaster, the employer may try to use personal characteristics of the job applicants like qualification, social background and gender to improve the match. In the framework of Bayesian decision making, observations available for employees (not for searchers) are used to make predictions concerning the job's true but unknown characteristics. As new information arrives, the forecast is revised and a quit decision is made. Therefore it is expected that separation rates decline with length of current job tenure. Since the acquisition of experience about the characteristics of different jobs requires some time, a positive effect of age on job tenure may be interpreted according to the job shopping and matching argument, too.

Idson and Feaster (1990) investigate wage differentials for employees working in firms of different size. According to their model employees in larger firms receive a greater return to on-the-jobtraining (assuming complementarity between human and physical capital, cf. Griliches 1969). Therefore, a higher level of on-the-job-training is expected in larger firms. 


\section{Model and Estimation Method}

\subsection{Modeling the failure times}

The aim of the empirical analysis is to detect dependences of the lengths of the employment spells on the explanatory variables. As in general a man experiences more than one spell in the observation period, we are in the statistical context of multivariate failure time analysis. The analysed employment spells are all of the same kind and we do not distinguish various destination states such as another job or unemployment. The successive spells of one employee are separated by recurrent events (job changes) or by intervening spells (e.g. periods of unemployment).

One common way of modeling failure times is the class of accelerated failure time models where the logarithm of the duration depends on a linear predictor (of covariates and regression parameters) and on an error term (see standard textbooks such as Kalbfleisch and Prentice 1980, 33f, Lancaster 1990, 40f). Classical parametric methods in survival analysis in the context of unobserved heterogeneity lead to biased estimates of the regression parameters and do not admit any evidence of the kind of time dependence of the hazard rate. The method used here takes advantage of the information which is given by multiple observations for one person. It does neither need any information about the distribution of the failure times and the time dependence of the hazard rate nor does it give any results concerning this problem but it does estimate the regression parameters reliably. We consider the following extension of an accelerated failure time model allowing for unobserved heterogeneity.

The data consist of $N$ employees $(n=1, \ldots, N)$ with a varying number $K_{n}$ of employment spells $\left(k=1, \ldots, K_{n}\right)$, each of which is at least partially observed during the observation period. The lengths of the spells $T_{n k}$ are influenced by a vector $x_{n k}$ of covariates (which may vary from spell to spell but stay constant during each spell) according to

$$
y_{n k}:=\ln \left(T_{n k}\right)=\beta_{0}+x_{n k}^{\prime} \beta+\sigma_{\alpha} \alpha_{n}+\sigma_{\varepsilon} \varepsilon_{n k}
$$

The stochastic component consists of an individual effect $\alpha_{n}$ which absorbs non-observed covariates and an error term $\varepsilon_{n k}$. The $\alpha_{n}$ are assumed to be independent and identically distributed. The $\varepsilon_{n k}$ can but need not be independent, their distribution is assumed to be one of the usual 
distributions in accelerated failure time models: The normal distribution leads to the Log-normal model, the logistic distribution to the Log-logistic model, and the extreme value distribution to the Weibull model. But note that in the analysis we use a nonparametric estimation method so that the kind of distribution need not be specified. For simplicity, $\alpha_{n}$ and $\varepsilon_{n k}$ are standardized to mean zero and standard deviation one.

Thus, in the special case of independent $\varepsilon_{n k}$ we have an equicorrelation structure with

$$
\begin{aligned}
& \operatorname{Cov}\left(y_{n k}, y_{m l}\right)=0 \text { if } n \neq m, \\
& \operatorname{Cov}\left(y_{n k}, y_{n l}\right)=\sigma_{\alpha}^{2} \quad \text { if } k \neq l,
\end{aligned}
$$

and

$$
\operatorname{Var}\left(y_{n k}\right)=\sigma_{\alpha}^{2}+\sigma_{\varepsilon}^{2} \forall n=1, \ldots, N \forall n=1, \ldots, K_{n}
$$

The observation of the employment histories breaks off with the end of 1990. Employment spells which continue beyond this time are included as censored spells. Instead of $T_{n k}$ we observe $z_{n k}=\min \left(T_{n k}, c_{n k}\right)$ together with an indicator variable $\delta_{n k}$ defined as 1 if $T_{n k} \leq c_{n k}$ and

0 if $T_{n k}>c_{n k}$ where the time span $c_{n k}$ from the beginning of the spell to the end of the observation period is independent of $T_{n k}$.

\subsection{Distribution-free estimation of the effects}

As no one can be sure of the correlation structure and the distribution of the failure times, we use a distribution-free method for the estimation of the regression parameters which accounts for unobserved heterogeneity and censored spells. For a more detailed description and simulation studies see Hornsteiner and Hamerle (1996).

This method combines the generalized estimating equations (GEE) approach (Liang and Zeger, 1986) with the replacement of censored times with values imputed along lines used by Buckley and James (1979). 
Strategies for treating regression models for correlated but continuous and normal distributed responses are the Aitken (1935) estimator or the Feasible Generalized Least Squares (FGLS) approach (Greene, 1993). Generalized linear models (GLM) are regression models to analyse discrete or continuous but not necessarily normal distributed outcome variables. These methods were combined by Liang and Zeger (1986) - where the effect of the covariables on the response variable is in the foreground but the correlation between the response variables is regarded as nuisance parameter - and these so called marginal models were solved by the GEE.

In opposition to the parametric models which were introduced to describe failure times in technical sciences and to the semiparametric Cox model which assumes proportional hazards and is still used mainly in medical applications, there exists another semiparametric approach, the accelerated failure time model which explicitly does not state any distribution assumption about the error term.

Buckley and James (1979) solved the problem of censored failure times in this kind of model by an extension of the Least Squares method. Every censored observation is replaced by its estimated conditional expectation given the information that this failure time is longer than the observed censor time. Here again the effect of the covariables on the response (the failure time) is the point of interest, not the kind of distribution.

The generalized estimating equations for the introduced model are

$$
\sum_{n=1}^{N} X_{n}^{\prime} V_{n}^{-1}\left(y_{n}^{*}-X_{n} \hat{\beta}\right)=0,
$$

where $X_{n}$ is the matrix containing the lines $x_{n k}^{\prime}, k=1, \ldots, K_{n}$, the covariance matrix $V_{n}$ depends on an assumption about the correlation structure within the clustered failure times and $y_{n}^{*}=\left(y_{n 1}^{*}, \ldots, y_{n K_{n}}^{*}\right)^{\prime}$ is a vector consisting of the observed non-censored values and, in the cases of censored spells, of their conditional expectations, thus

$$
y_{n k}^{*}=\delta_{n k} \ln z_{n k}+\left(1-\delta_{n k}\right) \hat{E}\left(y_{n k} \mid y_{n k}>\ln z_{n k}\right)
$$

These expectations are estimated by the estimation of the distribution of the residuals using the nonparametric product limit estimator (Kaplan and Meier 1958) which can be regarded as an extension of the empirical distribution for censored data. One feature of the GEE approach is that it 
works well also when the ,working correlation“ is not specified correctly. On the other hand, a working correlation which is similar to the real one improves the efficience of the estimator. In this analysis we use the equicorrelation assumption.

The iterative algorithm for solving the estimating equations consists of three steps in each iteration. We get an initial estimation simply by $\hat{\beta}^{(0)}=(\tilde{X}, \tilde{X})^{-1} \tilde{X}, \tilde{y}$ where $\tilde{X}$ and $\tilde{y}$ only include the uncensored spells. The first step of the $u^{\text {th }}$ iteration $(u=1,2, \ldots)$ is the imputation part in which $\hat{\beta}^{(u-1)}$ is used for computing residuals and the (renewed) $y_{n k}^{*(u)}$. Both $\hat{\beta}^{(u-1)}$ and $y_{n k}^{*(u)}$ enter into the second step, the moment estimations of

$$
v=\operatorname{Var}\left(y_{n k}^{*}\right)
$$

and

$$
c=\operatorname{Cov}\left(y_{n k}^{*}, y_{n l}^{*}\right)
$$

All these are the basis for the third part, the modified Fisher scoring

$$
\hat{\beta}^{(u)}=\hat{\beta}^{(u-1)}+\left(\sum_{n=1}^{N} X_{n}^{\prime} \tilde{V}_{n}^{-1}\left(\hat{\beta}^{(u-1)}\right) \frac{\partial}{\partial \beta}\left(y_{n}^{*}-X_{n}^{\prime} \hat{\beta}^{(u-1)}\right)\right)^{-1}\left(\sum_{n=1}^{N} X_{n}^{\prime} \tilde{V}_{n}^{-1}\left(\hat{\beta}^{(u-1)}\right)\left(y_{n}^{*}-X_{n}^{\prime} \hat{\beta}^{(u-1)}\right)\right)
$$

$u=1,2, \ldots$ (see Liang and Zeger 1986). These three steps are repeated until either convergence criteria are fulfilled or a cycle of Buckley-James typical oscillating values is detected (see Miller 1981, 152 and Currie 1996). 
An estimator of the asymptotic covariance matrix of the parameter estimations is

$$
\begin{aligned}
\operatorname{Cov}(\hat{\beta})= & \left(\sum_{n=1}^{N} X_{n}^{\prime} \tilde{V}_{n}^{-1} \frac{\partial}{\partial \beta}\left(y_{n}^{*}-X_{n}^{\prime} \hat{\beta}^{(u-1)}\right)\right)^{-1}\left(\sum_{n=1}^{N} X_{n}^{\prime} \tilde{V}_{n}^{-1} \operatorname{Cov}\left(y_{n}^{*}\right) \tilde{V}_{n}^{-1} X_{n}\right) \\
& \left(\sum_{n=1}^{N} X_{n}^{\prime} \tilde{V}_{n}^{-1} \frac{\partial}{\partial \beta}\left(y_{n}^{*}-X_{n}^{\prime} \hat{\beta}^{(u-1)}\right)\right)^{-1}
\end{aligned}
$$

where $\operatorname{Cov}\left(y_{n}^{*}\right)=\left(y_{n}^{*}-x_{n}^{\prime} \beta\right)\left(y_{n}^{*}-x_{n}^{\prime} \beta\right)^{\prime}$.

A measure for the extent of the remaining unobserved heterogeneity is $\hat{c} / \hat{v}$ - the estimated correlation of the transformed failure times within one employee. Also in the case of unobserved heterogeneity the applied methods promise unbiased estimators of the included variable effects.

\subsection{Data and Variables}

At the Federal Employment Office (Bundesanstalt für Arbeit) a file is constructed as an insurance account for each employee covered by the social security system in Germany. It contains the information about notices of the beginning or the end of an employment or yearly notices or notices in case of change regarding the insurance (so called historic file of the Employment Statistic). Thus, this procedure guarantees a continuous employment history for employees covered by social security and it is justified to regard the employment statistic as one of the datasets in Germany, , (...) that constitute the backbone of German social statistics (...) “. (Alba et al. 1994, 66)

The following analysis is based on a $1 \%$ random sample from the historical file of the Institute for Employment Research (IAB-Subsample) ensuring representativity of the analysis for all employees covered by the social security system. For the scientific community there is an anonymized version available (cf. Bender and Hilzendegen 1995, Bender et al. 1996). Since the main advantages of the IAB-Subsample is that the problems of attrition (panel mortality) and errors-in-variables (memory errors of retrospectively collected data) are minimal, the IAB-Subsample is especially suited for longitudinal analysis.

The IAB-Subsample covers an observation period between 01.01.1975 and 31.12.1990. It comprises the possible censored work history of more than 460,000 persons. Cross-section analyses can be carried out for 200,000 persons in each year. 
The variables comprised in the historic file (as well as in the IAB-Subsample) are based on the notices of the employers to the relevant social security institutions, which transmit them to the Federal Employment Office. Due to the fact that only employment spells of persons covered by the social security system are registered, self-employed, civil servants, family workers as well as employees, who are only irregularly employed or earn less than a certain small amount per month are not covered in this file, so that information exists for about $80 \%$ of all employed persons (cf. Herberger and Becker 1983).

The variables in the notices are legally prescribed. Variables at the individual level are age, sex, personal status, nationality as well as professional qualification, occupational status as well as the gross earnings (up to the limit of the compulsary insurance), and at the establishment level the company code, industry affiliation, establishment size, as well as the site of the company. Additionally, the IAB-Subsample contains information about the periods when persons are in receipt of unemployment benefit and assistance as well as subsistance allowance during training courses. Especially these variables are of great accuracy as they form the basis for individual claims for pensions and unemployment insurance. So the gross earnings and the dates of the beginning and ending of jobs are highly precise. ,Much of the important information about state dependence in mobility unfolds very early on the job, and data on the job durations that can be calibrated only annually or even quarterly are not likely to be informative.“ (Farber 1994, 555).

The model is estimated on the basis of employment spells defined as a notice in the employment statistics register which refers to the starting and ending date of an employment spell and its corresponding wage received for that time period.

The change in the youth labor market affect the career opportunities at the point of entry into the labor market. Thus, the structural context at the point in time people start their careers has a substantial impact upon people's subsequent careers. This kind of influence is generally called cohort effect which is controlled by the comparison of two cohorts of young men, entering the labor market 1979 during a boom and during a slump of the business cycle (1985).

The years were also selected, because the number of years after 1985 is large enough to allow a sufficient number of transitions during the time span covered in the sample. In fact, in the year 1979, the capacity utilized was 99.9 which is the highest value for the years since 1961 (Council of Economic Advisors 1996, 26*). The three years preceeding 1985 had lower $(1982,1983)$ or the same (1984) rates of capacity utilization than 1985 and the years 1986-1988 experienced even lower 
rates than 1985. However, the unemployment rate was both lower in the years before 1985 and lower until 1994 (Council of Economic Advisors 1996, Table 21*).

Therefore, members of the 1979 and 1985 cohorts had to fulfill the condition that their first notice in the employment statistic register must be in the respective years. Additionally, the birth year of different occupational groups was controlled by the time, which is on average necesssary, e.g., to receive secondary school leaving certificate (13 years), to complete an apprenticeship or graduate from a full-time vocational school (3 years), to graduate from a university (18 years) or a specialized college of higher education (Fachhochschule, 15 years) (cf. Bellmann et al. 1994, 49f). For persons with a lower schooling level and no occupational qualification 10 years were assumed as schooling time.

Heckman (1981) emphasizes the importance of the distinction between ,true state dependence“ and „spurious state dependence“. In the „true“ case once a person experiences an event, her behaviour or opportunities change compared with an otherwise identical person who has not experienced this event. In the „spurious“ case, past experience has no effect on the probability of experiencing the event in the future. However, in general one cannot properly control for all the variables that distinguish one individual's decision from another's. Past experience may be a good proxy for these omitted variables. However, the effect of past experience is overstated if it is not controlled adequately for heterogeneity caused by the influence of unmeasured variables. Heckman (1981) himself argued that it is also plausible to conjecture that „lagged employment“ might serve as a good ,proxy“ for the effect of heterogeneity. Recently, Farber (1994) has used the term „heterogeneity“ to refer to differences among workers in their probability of leaving a particular job conditional on worker characteristics and past labor force history up to the start of the job. Thus, heterogeneity in workers' propensities to change jobs is not necessarily fixed over time or unaffected by labor force history on earlier jobs. With our data and our method of analysis, it is possible to follow this line by using variables for both for the number of employment and unemployment spells as well as the number of transitions from out-of-the-labour-force (gap transitions).

The selection of cases was carried out according to the following rules:

1. Women are excluded from the present study, since they show very different occupational structures and mobility patterns, since periods of active labour force participation are interspersed with periods out of the labour force due to family and home work.

2. Persons in more than one job for each time are excluded from the analysis. 
3. Employees working in agriculture are excluded because of seasonal work which is not comparable with employees in other industries.

The numbers of employees who enter the analysis and the description of the variables for the transitions of the two cohorts (1979 and 1985) are shown in table 1 and 2.

*** Table 1: Numbers of employees and transitions

*** Table 2: Description of the variables for the transitions of the two cohorts (1979 and 1985)

\section{Results}

The interpretation of the parameter of the estimated model is that positive coefficients prolong the employment spells whereas negative ones decrease their length. ${ }^{3}$ Table 3 presents the results obtained for the two cohorts with members starting the working career during the boom 1979 and the economic slump 1985. The differences between the two cohorts are rather small - only in three cases (of 28) do the estimated coefficients have different signs: The effect of construction industry was negative and significant in 1979 and positive but insignificant in 1985 . The effects of one and two former gap transitions were negative and significant in 1979, positive and significant in the one time case and positive and insignificant in the two time case in 1985. The effect of military service could theoretically differ between the two cohorts. Restricting the potential gap caused by military service in the cohort starting in 1979 to the same time span as in the cohort strating in 1985 reveals no significant changes in the results obtained. Therefore, we can interpret the estimates for both cohorts together.

\section{*** Table 3: Estimation Results}

Although the influence is not monotone, the employees in larger establishments have significantly longer job durations in comparison to employees in establishments with only one employee. Employees in the business and personal services experience shorter job attachments than those in the production industries. The results corroborate the hypothesis derived from Idson and Feaster (1990) that employees in larger firms have higher levels of on-the-job training and thus their 
employees are inclined to stay longer with their jobs. Aside from the establishment size effect the employees in service industries seem to have less specific human capital accumulated than those in the production industries. Furthermore, the services attract those employees who have a desire for independence.

The highly significant age effect can be interpreted as indication that „good“ matches endure and employees with accumulated human capital through work experience keep their jobs. The relationship between general (transferable) and specific human capital is not along the qualification level. The most relevant simple effect stems from the apprenticeship. Lower secondary school leavers with a completed apprenticeship stay longer then employees with other qualifications on their jobs. The positive and significant effect of the dummy indicating a switch from apprenticeship training points into the same direction.

Thus, in accordance with results from Lynch (1991) and Booth and Satchell $(1994,1996)$ for the U.S. and Britain our empirical results indicate that completed apprenticeships tend to reduce labour mobility. Both employers and employees with completed apprenticeships actually continue their employment relationship. This allows the firms to recoup their training costs not only during the period of ,indenture“, so that the poaching problem may be solved.

The lower coefficients for the members of thecohort of that men hired during good times imply that they do not loose that advantage during their subsequent career. This implies that they tend to work at „good“ jobs not because they are more suited to good jobs but rather that they are more likely to stay with a „good“ job. The reason lies in the fact that they do not get alternative opportunities that exceed those in their current organization. Lazear $(1993,97 \mathrm{f}$.) argues that to the extent that some of the human capital is firm specific, a worker who has already been given the opportunity to invest has increased the value of his time at the current firm, relative to his alternatives. The more he invests the bigger is the gap between his productivity at the current firm and bis expected alternative use of time. This makes him less and less likely to leave.

The relevance of heterogeneity controls is demonstrated by the significant influence of the variables for the number of employment and unemployment spells. The more often employees experience unemployment spells and the higher the number of employment spells prior to the job under study

${ }^{3} \mathrm{~A}$ value of 0.620 for the apprenticeship dummy means that the individuals coming from an apprenticeship training have a duration of the subsequent employment spells which is $\exp (0.620)=1.86$ times longer 
the shorter is the expected employment duration. Additionally, following the arguments given in Heckman (1981) and Farber (1994), the inclusion of these heterogeneity controls serves to avoid spurious regression results.

The estimation results show that the included variables do not suffice for a total disappearance of unobserved heterogeneity. A measure for the extent of the remaining unobserved heterogeneity is $\hat{c} / \hat{v}$ - the estimated correlation of the transformed failure times within one employee - which is 0.217 for the 1979 cohort but 0.521 for the 1985 cohort, which means that in the latter case the included variables cannot explain the failure times as well as in the former case. Nevertheless, the applied methods promise unbiased estimators of the included variable effects in both cases.

\section{Conclusions}

Microeconomic theories provide some interesting arguments about the determinants of the duration of employment spells. We tested some of them on the basis of a large micro data set using information from the German employment statistic register. The data contain personal characteristics and labor demand variables (establishment size and industry affiliation) and proxy variables for the heterogeneity within the two cohorts we consider. The effects are estimated by a distribution-free method which combines the generalized estimating equations approach for longitutional data with the replacement of censored cases by imputed values.

The most important findings of this study are that employees stay longer in larger establishments and in production industries. Older individuals, those with completed apprenticeship training and those coming directly from apprenticeship training have longer job durations. Thus, an apprenticeship system can be regarded upon as an institution solving the poaching problem (cf. Booth and Satchell 1994,1996). Our results are consistent with the arguments provided by Idson and Feaster (1990) concerning the importance of long-lasting jobs in larger firms.

Besides the control for unobserved heterogeneity the second unique contribution of the paper is the analysis based on data of a relative long cohort which allows to assess the effect of the number of unemployment and employment spells. It turns out that the larger the number of unemployment and employment spells the shorter is the job attachment expected. These results are in line with the analysis of Farber (1994) about the effect of past labor force history up to the start of the job. 


\section{References}

Alba, R.D., W. Müller, and B. Schimpl-Neimanns, 1994, Secondary analysis of official statistics, in: I. Borg and P. Ph. Mohler, eds., Trends and perspectives in empirical social research (de Gruyter, Berlin, New York) 57-78.

Aitken, A., 1935, On least squares and linear combinations of observations, Preceedings of the royal statistical society $55,42-48$.

Bellmann, L., A. Reinberg, and M. Tessaring, 1994, Bildungsexpansion, Qualifikationsstruktur und Einkommensverteilung - Eine Analyse mit Daten des Mikrozensus und der Beschäftigtenstatistik, in R. Lüdeke, ed., Bildung, Bildungsfinanzierung und Einkommensverteilung II (Duncker \& Humbolt, Berlin) 13-70.

Bender, S. and J. Hilzendegen, 1995, Die IAB-Beschäftigtenstichprobe als scientific use file, Mitteilungen aus der Arbeitsmarkt- und Berufsforschung 28, 76-95.

Bender, S., J. Hilzendegen, G. Rohwer and H. Rudolph, 1996, Die IAB-Beschäftigtenstichprobe 19751990. Beiträge zur Arbeitsmarkt- und Berufsforschung 197 (Institut für Arbeitsmarkt- und Berufsforschung der Bundesanstalt für Arbeit, Nürnberg).

Berkovec, J. and St. Stern, 1991, The exit behaviour of older men, Econometrica 59, 189-210.

Booth, A. L. and St. Satchell, 1996, On apprenticeship qualifications and labour mobility, in: A.L. Booth and D. J. Snower, eds., Acquiring skills (Cambridge University Press) 285-302

Booth, A.L. and St. Satchell, 1994, Apprenticeships and job tenure: a competing risks model with time-varying covariates, Oxford Economic Papers 46, 676-695.

Buckley, J. and I. James, 1979, Linear regression with censored data, Biometrika 66, 429-436.

Council of Economic Advisors, 1996, Jahresgutachten 1996/97 (Bonn).

Currie, I. D., 1996, A note on Buckley-James estimators for censored data, Biometrika 83, 912-915.

Farber, H. S., 1994, The Analysis of Inter-firm Worker Mobility, Journal of Labor Economics 12, 554-593. 
Greene, W., 1993, Econometric Analysis (Macmillan, New York)

Griliches, Z., 1969, Capital-skill complementarity, Review of Economics and Statistics 51, 465-468.

Gronberg, T.J. and W.R. Reed, 1994, Estimating workers' marginal willingness to pay for job attributes using duration data, Journal of Human Resources 29, 911-931.

Hartog, J, 1981, Wages and allocation under imperfect information, De Economist 129, 311-323.

Hashimoto, M., 1979, Bonus payment, on-the-job training and life time employment in Japan, Journal of Political Economy 87, 1086-1104.

Heckman, J. J., 1981, Heterogeneity and state dependence, in: S. Rosen, ed., Studies in labor markets (University Press, Chicago) 91-139.

Herberger, L. and B. Becker, 1983, Sozialversicherungspflichtig Beschäftigte in der Beschäftigtenstatistik und im Mikrozensus, Wirtschaft und Statistik, 290-304.

Hornsteiner, U. and A. Hamerle, 1996, A combined GEE/Buckley-James method for estimating an accelerated failure time model of multivariate failure times. Discussion Paper 47 (Sonderforschungsbereich 386, Ludwig-Maximilians-Universität München).

Idson, T. L. and D.J. Feaster, 1990, A selectivity model of employer size wage differentials, Journal of Labor Economics 8, 99-122.

Johnson, W. R., 1978, A theory of job shopping, Quarterly Journal of Economics 92, 261-277.

Jovanovic, B., 1979, Job matching and the theory of turnover, Journal of Political Economy 87, 972-990.

Kalbfleisch, J. D. and R.L. Prentice, 1980, The statistical analysis of failure time data (Wiley, New York).

Kaplan, E. L. and P. Meier, 1958, Nonparametric estimation from incomplete observations, Journal of the American Statistical Association 53, 457-481.

Lancaster, T., 1990, The econometric analysis of transition data (University Press, Cambridge).

Lazear, E.P., 1993, Personnel Economics (MIT Press, Cambridge, Mass.). 
Levine, D. I., 1991, Just-cause employment policies in the presence of worker adverse selection, Journal of Labor Economics 9, 294-305.

Liang, K,-Y. and S.L. Zeger, 1986, Longitudinal data analysis using generalized linear models. Biometrika 73, 13-22.

Lynch, L.M., 1991, The role of off-the-job vs. on-the-job training for the mobility of women workers, American Economic Review Papers and Procceedings 81, 151-155.

Meitzen, M.E., 1986, Differences in male and female quitting behaviour, Journal of Labor Economics 4, 151-167.

Miller, R G. jr., 1981, Survival analysis (Wiley, New York).

Mortensen, D.T., 1986, Job search and labor market analysis, in: O. Ashenfelter and R. Layard, eds, Handbook of Labor Economics, Vol. 2 (North-Holland, Amsterdam) 849-919.

OECD, 1993, Employment Outlook (Paris).

Parsons, D. O., 1972, Specific human capital: an application to quit rates and layoff rates, Journal of Political Economy 80, 1120-1143.

Parsons, D. O., 1986, The employment relationship: job attachment, work effort, and the nature of contracts, in: O. Ashenfelter and R. Layard, eds, Handbook of Labor Economics, Vol. 2 (NorthHolland, Amsterdam) 789-849.

Schasse, U., 1991, Betriebszugehörigkeitsdauer und Mobilität (Campus, Frankfurt a.M.).

Spilerman, S., 1977: Careers, labor market structure, and socioeconomic achievement, American Journal of Sociology 83, 551-593.

Stevens, M., 1994, A theoretical model of on-the-job training with imperfect competition, Oxford Economic Papers 46, 537-562.

Stevens, M., 1996, Transferable training and poaching externalities, in: A.L. Booth and D. J. Snower, eds., Acquiring skills (Cambridge University Press) 21-40.

Viscusi, W., 1980, A theory of job shopping: a Bayesian perspective, Quarterly Journal of Economics 94, 609-614. 
Table 1: Numbers of employees und transitions in the sample

\begin{tabular}{|l|r|r|}
\hline & \multicolumn{1}{|c|}{1979} & \multicolumn{1}{|c|}{1985} \\
\hline Total number of employees & 4134 & 4312 \\
Total number of transitions & 15143 & 9490 \\
Right censored number of transitions & 3804 & 3940 \\
in \% of total number of employees & 92,02 & 91,37 \\
\hline
\end{tabular}


Table 2: Description of the variables for the transitions of the two cohorts (1979 and 1985)

\begin{tabular}{|c|c|c|}
\hline & 1979 & 1985 \\
\hline \multicolumn{3}{|l|}{ establishment size } \\
\hline unknown & 2.29 & 2.23 \\
\hline 1 employee & 2.51 & 2.14 \\
\hline 2-9 employees & 20.13 & 18.96 \\
\hline 10-19 employees & 12.77 & 10.84 \\
\hline 20-49 employees & 14.85 & 13.30 \\
\hline 50-99 employees & 9.45 & 9.96 \\
\hline 100-499 employees & 18.44 & 20.59 \\
\hline 500-999 employees & 6.19 & 7.67 \\
\hline$>=1000$ employees & 13.37 & 14.31 \\
\hline In age (at the beginning of the spell) & 3.1517 & 3.0767 \\
\hline \multicolumn{3}{|l|}{ industry } \\
\hline production & 42.57 & 44.92 \\
\hline construction & 17.84 & 12.83 \\
\hline business services & 18.33 & 18.60 \\
\hline personal services & 21.26 & 23.65 \\
\hline $\begin{array}{l}\text { recall (from intervening unemployment and/or out-of-labour-force } \\
\text { spells) }\end{array}$ & 29.27 & 28.26 \\
\hline \multicolumn{3}{|l|}{ \# former unemployment transitions } \\
\hline & 53.65 & 77.47 \\
\hline one time & 21.37 & 15.89 \\
\hline two times & 11.15 & 4.58 \\
\hline more than two times & 13.83 & 2.06 \\
\hline \multicolumn{3}{|l|}{ \# former gap transitions } \\
\hline no & 41.79 & 64.43 \\
\hline one time & 33.80 & 24.82 \\
\hline two times & 12.88 & 6.23 \\
\hline more than two times & 11.53 & 4.52 \\
\hline \multicolumn{3}{|l|}{ \# former employment transitions } \\
\hline & 29.41 & 45.87 \\
\hline one time & 23.65 & 26.65 \\
\hline two times & 16.56 & 13.73 \\
\hline more than two times & 30.38 & 13.75 \\
\hline \multicolumn{3}{|l|}{ qualification } \\
\hline unknown & 5.73 & 5.87 \\
\hline lower secondary school without completed apprenticeship & 27.55 & 35.35 \\
\hline $\begin{array}{l}\text { Secondary school leaving certificate without or with completed } \\
\text { apprenticeship }\end{array}$ & 4.30 & 6.54 \\
\hline lower secondary school with completed apprenticeship & 55.74 & 47.20 \\
\hline graduates with a university type education & 6.68 & 5.04 \\
\hline establishment switch was directly from apprenticeship training & 13.76 & 22.74 \\
\hline
\end{tabular}


Table 3: Estimation Results

\begin{tabular}{|c|c|c|}
\hline & 1979 & 1985 \\
\hline$\hat{\beta}_{0}$ & $\begin{array}{l}-18.9 \\
{[0.46]}\end{array}$ & $\begin{array}{l}-19.2 \\
{[1.03]}\end{array}$ \\
\hline $\begin{array}{l}\text { establishment size (1 employee) } \\
\text { unknown }\end{array}$ & $\begin{array}{c}-0.235 * \\
{[0.114]}\end{array}$ & $\begin{array}{c}-0.394 * \\
{[0.170]}\end{array}$ \\
\hline 2-9 employees & $\begin{array}{l}0.182 * \\
{[0.088]}\end{array}$ & $\begin{array}{c}0.194 \\
{[0.127]}\end{array}$ \\
\hline 10-19 employees & $\begin{array}{l}0.170 \\
{[0.091]}\end{array}$ & $\begin{array}{l}0.202 \\
{[0.138]}\end{array}$ \\
\hline 20-49 employees & $\begin{array}{l}0.180 * \\
{[0.090]}\end{array}$ & $\begin{array}{l}0.247 \\
{[0.132]}\end{array}$ \\
\hline 50-99 employees & $\begin{array}{l}0.158 \\
{[0.093]}\end{array}$ & $\begin{array}{l}0.210 \\
{[0.141]}\end{array}$ \\
\hline 100-499 employees & $\begin{array}{l}0.159 \\
{[0.090]}\end{array}$ & $\begin{array}{l}0.310 * \\
{[0.132]}\end{array}$ \\
\hline 500-999 employees & $\begin{array}{l}0.339 * * \\
{[0.104]}\end{array}$ & $\begin{array}{l}0.430 * * \\
{[0.152]}\end{array}$ \\
\hline$>=1000$ employees & $\begin{array}{l}0.490 * * \\
{[0.098]}\end{array}$ & $\begin{array}{l}0.598 * * \\
{[0.147]}\end{array}$ \\
\hline In age (at the beginning of the spell) & $\begin{array}{l}8.363^{\star \star} \\
{[0.152]}\end{array}$ & $\begin{array}{l}8.351^{\star \star} \\
{[0.343]}\end{array}$ \\
\hline $\begin{array}{l}\text { industry (production) } \\
\text { construction } \\
\text { business services } \\
\text { personal services }\end{array}$ & $\begin{array}{l}-0.100 * \\
{[0.039]} \\
-0.201 * \star \\
{[0.042]} \\
-0.352 * \star \\
{[0.044]}\end{array}$ & $\begin{array}{l}0.004 \\
{[0.075]} \\
-0.174 * \\
{[0.076]} \\
-0.336 * \star \\
{[0.071]}\end{array}$ \\
\hline $\begin{array}{l}\text { recall recall (from intervening unemployment and/or out-of- } \\
\text { labour-force spells) }\end{array}$ & $\begin{array}{l}-0.413 * \star \\
{[0.029]}\end{array}$ & $\begin{array}{l}-0.564 \star \star \\
{[0.047]}\end{array}$ \\
\hline $\begin{array}{l}\text { \# former unemployment transitions }(0) \\
\text { one time } \\
\text { two times } \\
\text { more than two times }\end{array}$ & $\begin{array}{l}-0.702 * \star \\
{[0.045]} \\
-0.931 * \star \\
{[0.063]} \\
-1.277 * \star \\
{[0.072]}\end{array}$ & $\begin{array}{l}-0.791 * \star \\
{[0.083]} \\
-0.804 * \star \\
{[0.165]} \\
-0.481 \\
{[0.294]}\end{array}$ \\
\hline $\begin{array}{l}\text { \# former gap transitions (0) } \\
\text { one time } \\
\text { two times } \\
\text { more than two times }\end{array}$ & $\begin{array}{l}-0.165 * \star \\
{[0.039]} \\
-0.273 * \star \\
{[0.063]} \\
-0.675 * \star \\
{[0.080]}\end{array}$ & $\begin{array}{l}0.180 * \\
{[0.079]} \\
0.103 \\
{[0.140]} \\
-0.252 \\
{[0.196]}\end{array}$ \\
\hline
\end{tabular}




\begin{tabular}{|c|c|c|}
\hline \multicolumn{3}{|l|}{ \# former employment transitions $(0)$} \\
\hline one time & $-0.976 * *$ & $-0.688 * *$ \\
\hline & {$[0.039]$} & {$[0.061]$} \\
\hline \multirow[t]{2}{*}{ two times } & $-1.132 * \star$ & $-0.634 * \star$ \\
\hline & {$[0.051]$} & {$[0.094]$} \\
\hline \multirow[t]{2}{*}{ more than two times } & $-1.254 * \star$ & $-0.371 \star$ \\
\hline & {$[0.064]$} & {$[0.148]$} \\
\hline \multicolumn{3}{|l|}{$\begin{array}{l}\text { qualification (lower secondary school without completed } \\
\text { apprenticeship) }\end{array}$} \\
\hline \multirow[t]{2}{*}{ unknown } & $-0.212 * *$ & $-0.357 * *$ \\
\hline & {$[0.073]$} & {$[0.104]$} \\
\hline \multirow{2}{*}{$\begin{array}{l}\text { secondary school leaving certificate without or with completed } \\
\text { apprenticeship }\end{array}$} & $-1.149 * *$ & $-0.734 * *$ \\
\hline & {$[0.085]$} & {$[0.130]$} \\
\hline \multirow[t]{2}{*}{ lower secondary school with completed apprenticeship } & $0.302 * \star$ & $0.777 \star \star$ \\
\hline & {$[0.041]$} & {$[0.073]$} \\
\hline \multirow[t]{2}{*}{ graduates with a university type education } & $-0.821 * \star$ & $-0.831 * \star$ \\
\hline & {$[0.105]$} & {$[0.244]$} \\
\hline \multirow{2}{*}{ establishment switch was directly from apprenticeship training } & $0.620 * \star$ & $0.908 * \star$ \\
\hline & {$[0.044]$} & {$[0.066]$} \\
\hline$\hat{v}$ & 1.55 & 1.83 \\
\hline$\hat{c}$ & 0.34 & 0.95 \\
\hline
\end{tabular}

Remarks: The duration of a job is defined as actual employment within the same establishment. A transition from on job to another is defined by a change of the establishment code. The reference group is given in parantheses behind the variable name and the standard errors are under the estimated coefficients. *(**) means significance at the 5\% (1\%) level of a two-sided test. 